\title{
FINANCIAL PERFORMANCE, INTANGIBLE ASSETS AND VALUE CREATION IN BRAZILIAN AND CHILEAN INFORMATION TECHNOLOGY COMPANIES.
}

CHIARELLO, Tânia Cristina*

PLETSCH, Caroline Suzbach

DA SILVA, Alini

DA SILVA, Tarcísio Pedro

\begin{abstract}
Intangible assets disclosure, even with recent obligation, has brought benefits to companies' value and financial performance assistance. This study aims at analyzing the relationship between financial performance, intangible assets disclosure and value creation within Brazilian and Chilean information technology companies. In order to carry out the survey a descriptive analysis through both documentary research and quantitative approach was used. Descriptive statistics analysis, t-test and Pearson's correlation helped confirm that Chilean companies disclose more intangible assets and make greater value through reaching good results in financial performance. Thus, the higher the financial performance, the greater the value creation, and the greater the intangible assets disclosure within Chilean information technology companies.
\end{abstract}

Keywords: Intangible assets, value creation, financial performance.

\section{INTRODUCTION}

Financial accounting aims at providing data for external users, such as investors, creditors and government agencies in need of information for decision making (Jiambalvo, 2002). Users dependent on accounting data to guide their performance information and decisions find benefits in managerial information accounting (Horngren, 1985).

Accounting plays an important role in providing information for company's financial performance analysis. Indicator analysis assists in both financial planning and organizational performance monitoring (Groppelli \& Nikbakht2002).

The analysis of economic and financial indicators requires interpretation aiming at monitoring company's financial performance. In order to achieve that, financial statements are used as source for calculating indicators. Thus, financial performance measures are considered very important management tools (Gitman, 2010).

Solomon and Pringle (1981) emphasize that the analysis of the financial performance within an organization requires comparison standards. These help the company find its evolution in more than a period, because knowing the indicators of only one period is not enough for assessing a company's financial situation. Besides analyzing evolution in more than one period, Groppelli and Nikbakht (2002) add that financial performance analysis help compare a company's financial situation with that of its competitors.

Both globalization and information technology advancement have intensified competition between companies and made them differ from their competitors. Several authors have stated that wealth creation in business is related to intangible assets. They also argue that intangible assets are responsible for better financial performance and value

Tânia Cristina Chiarello, Rua Antônio da Veiga, no 140,sala 202, Victor Konder, Blumenau - SC, 89012-900, Brazil, tcchiarello@gmail.com. Caroline Sulzbach Pletsch, Rua Antônio da Veiga, no 140, sala 202, Victor Konder, Blumenau - SC, 89012-900, carol spletsch@yahoo.com.br. Alini da Silva, Rua Antônio da Veiga, no 140, sala 202, Victor Konder, Blumenau - SC, 89012-900, alinicont@gmail.com. Tarcísio Pedro da Silva, Rua Antônio da Veiga, no 140, sala 202, Victor Konder, Blumenau - SC, 89012900, tarcisio@furb.br 
creation. Thus, companies possessing more intangible assets tend to create more value for their shareholders (Perez \& Fama, 2006).

Financial performance can be defined "in terms of maximizing the owners' wealth" (Borba, 2005, p. 39). Assaf Neto (2010) asserts that organizations are focused on value creation in order to maximize their owners' wealth. Burksaitiene (2009) explains that Economic Value Added (EVA®) is a value creation measure. Tsai, Lu and Yen (2012) add that, due to its purpose regarding value creation, intangible assets evaluation has received more attention.

In this context, the purpose of this study is to answer the following question: what is the relationship between financial performance with both intangible assets disclosure and value creation in Brazilian and Chilean information technology companies? In order to answer this question, the objective of the study is to analyze the relationship between financial performance with intangible assets disclosure and value creation in Brazilian and Chilean information technology companies. In order to achieve such a goal, data from 2008 to 2012 were used. According to Assaf Neto (2012), it is important to perform a temporal comparison because this allows one to track the company's performance, which usually occurs in a three to five years period.

The choice of Brazilian and Chilean information technology companies was due to the fact that both nations are developing countries. Aravena, Cavada and Mulder (2012) argue that investment in information technology is growing at a similar level in Brazil and Chile.

Some studies dealing with information technology companies were reviewed. For example, Brito and Ferreira (2008) have studied variability structure of financial performance within Brazil's information technology companies and have found out the role that of size and productivity play on performance. Lima and Carmona (2011) have suggested that the value of intangible assets within information and communication technology companies is made up of human capital, knowledge management, structural capital and organizational environment. Vicenti, Staroski and Toledo (2012), considering the information technology companies listed by BM \& Fbovespa, have shown innovation level in organizational products, services, processes and marketing.

With regard to Brazilian and Chilean companies, Rogers, Mendes-da-Silva and Paula (2005) have discussed people's perception that productive diversity has negative impacts on Latin American companies' value. They have also concentrated on whether there is a relationship between productive diversification and value in Brazilian companies. Marcon, Grzebieluckas, Flag-De-Mello and Muller (2007) have investigated whether capital structure and financial performance differ among Brazilian, Argentine, and Chilean companies.

This research analyzed Brazilian and Chilean companies, using economic and financial data for the period from 2008 to 2012. The decision about the five years of the study derived from the research conducted by Bastos, Nakamura and Basso (2009). They have found the determinants of capital structure in Mexican, Brazilian, Argentine, Chilean and Peruvian companies, from 2001 to 2006. Bastos and Nakamura (2009) also have found in Brazilian, Mexican and Chilean companies the determinants of capital structure in the period 2001-2006. In their research, Costa and Garcias (2009) have analyzed market concentration and performance of Brazilian pulp and paper industries, between the years 2003 and 2007.

This research also seeks refuge within a research by Perez and Fama (2006), whose results can be used for both decision-making and financial performance monitoring in Brazilian and Chilean information technology companies. Besides, with emphasis on knowledge-based economy, intangible assets evaluation has become a topic of widespread interest, aiming at companies' value creation (Tsai, Lu \&Yen, 2012). 


\section{THEORETICAL FRAMEWORK}

This section discusses the study's theoretical support. It first addresses the topic of corporate financial performance and, then, covers the relevance of intangible assets and Economic Value Added (EVA).

\subsection{Corporate Financial Performance}

According to Cochran and Wood (1984), the definition of corporate financial performance is not debated in literature. Such a lack of discussion has caused disagreement on how to measure the phenomenon. Business performance is the kind of information toward which accounting institutions must show responsibility (Gasparetto, 2004).

However, one believes that corporate financial performance is divided into two general categories: the first one regards the return to the investor; the second one refers to accounting return (profit) (Cochran \& Wood, 1984). McGuire, Sundgren and Schneeweis (1988) argue that corporate financial performance uses both financial variables and capital market measures.

Another way to measure companies' financial performance was employed by Waddock and Graves (1997) and Mahoney and Roberts (2004), who used return on assets (ROA) and return on equity (ROE) rates.

Orlitzky, Schmidt, and Rynes (2003) have reviewed literature and found out that corporate financial performance is represented by three ways: the first one deals with market measures reflecting shareholders' level of satisfaction; the second one depicts the level of business efficiency through accounting measures; the third one refers to surveys with estimated financial performance.

Based on a bibliometrical study, Bonaventura, Silva and Bandeira-De-Mello (2012) indicated that, in the years 1996-2010, the most commonly used variables to represent the financial performance were ROA, ROE, sales growth, ROS (Return on Sales), contribution margin, Tobin's Q, market share, firm's risk, ROCE (Return on Capital), operating income, cash flow, share earnings.

Callan and Thomas (2009) conducted a study in USA in order to identify and test measures regarding both financial and social performance, willing to examine the relationship most commonly hypothetical between the two phenomena. Some of the results highlighted that a company's profitability measured by ROS is affected to a lesser extent by socially responsible activities for companies in the wholesale and retail markets than for companies in other sectors. Additional findings indicated that the measures of financial performance, such as ROA and ROS, tend to generate very consistent results. However, ROE seems to be more suitable for long-term analysis.

Moneva and Ortas (2010) conducted their work within European companies in order to equip literature with more debate on the relationship between the degree of environmental performance and corporate financial performance. The return of financial indicators was used on assets (ROA). Profit margin and return on equity (ROE) are relative values. Cash flow and operating profit result in positive relationship between environmental and financial performance.

In turn, Surroca, Tribo and Waddock (2010) analyzed the effects of intangible assets of a company on mediating the relationship between corporate responsibility and financial performance in 28 countries. For the analysis of the study various variables were used: financial performance and corporate responsibility to measure corporate performance; innovation, human capital, reputation and culture to assess intangible assets; physical resources, influence, financial resources, control, size and risk to evaluate tangible assets. 
The results indicated that there is no direct relationship between corporate responsibility and performance in only indirect financial relationship, which depends on the mediating effect of the company's intangible assets (Surroca et al., 2010).

Thus, it seems that current researchers continue to use the definition of financial performance with indicators relating company's efficiency, shareholders' satisfaction and estimates of financial performance.

As companies' goal to bring greater wealth to their owners was widespread early, the corporate financial performance, as Borba (2005) believes, is easily defined by measures such as profitability, market value, and return to shareholders.

From Assaf Neto's (2003) perspective, the analysis of company's financial performance is made possible by indexes and financial indicators when considering financial statements as sources of data and information, which bring historical performance reports and projections for the future, as well. Performance indicators, in turn, can show companies' strengths and weaknesses, thus, enabling corrective and proactive actions in certain decisions (Trentin, 2009).

Barney (1991) believes that one of the attributes leading to companies' competitive advantage refers to intangible assets, represented by innovation, human resources, reputation, organizational culture, among other intangible attributes.

Thus, in order to relate a company's value creation to financial performance and intangible assets disclosure, one believes that a mediating effect is effective for result achievement.

\subsection{Intangible assets}

Intangible is an asset without physical substance (CPC 04 (R1), 2010). In general, intangible assets are like any other asset. They generate future economic benefits under the control of an entity (Iudícibus, Martins, Gelbck \& Santos, 2010). Hendriksen and Van Breda (1999, p. 388) define intangible assets as "the assets that cannot be touched because they have no body".

Intangible assets are seen as the company's dynamic capacity, created by knowledge, organizational structure, innovative capacity, brand, research and development, and market share (Tsai et al., 2012). Intangible assets should be recognized when the generation of future economic benefits is probable, and when it is possible to measure the cost of the asset in a reliable way (CPC 04 (R1), 2010)

One can include, as future economic benefits generated by intangible assets, incomes from sale of products or services, cost savings or other benefits resulting from the use of the asset by the company. For example, the use of intellectual capital in production process can reduce future production costs rather than increase future revenues (CPC 04 (R1), 2010).

Intangible assets are gaining space. In some cases, they exceed the value of the tangible ones. For example, the brand of a company may be worth much more than its assets (Teixeira, Petri \& Marques, 2012). Companies seek ways to value creation, which aim at the best interaction between tangible and intangible assets (Perez \& Fama, 2006).

Intangible assets importance has become evident due to the great appreciation of companies with intensive use of assets. Tangible assets are easily acquired, since the company possesses financial position to do so. However, intangible assets are unique and owned by a single company. This makes it an important differentiating factor, contributing to the achievement of competitive advantage (Kayo, Kimura, a Martin \& Nakamura, 2006).

From Lev's (2001) point of view, intangible assets are sources of value without physical substance. They are generated by innovation, unique organizational projects and practices of human resources. Tangible and intangible assets often interact to create value 
and economic growth for the company. A company's market value is explained by the set of its tangible and intangible assets (Teixeira et al., 2012).

Globalization, information technology advancement, and facilities created by ecommerce have intensified competition among companies, helping them differentiate themselves from their competitors. Thus, intangible assets may allow differentiation between business and achievement of competitive advantage (Perez \& Fama, 2006).

According to Ciprian, Valentin, Madalina and Lucia (2012), the value of a company is largely determined by their intangible assets. Intellectual capital is considered the key factor of competitiveness, existing from the moment a seller sets a good relationship with a customer. For Niculiță, Stern and Caloian (2012), knowledge is nothing but a form of social capital. It is social because it involves a process performed by people in social environment. And it is capital because performance can generate financial value. The ability to innovate should be treated as worthy of value.

Axtle-Ortiz (2012) argues that intangible assets generate economic value to businesses, suggesting that the only way to manage these assets is both knowing its composition and recognizing its value within the entity.

\subsection{Economic value added (EVA®)}

It was based on the concept of economic profit, approached by economist Alfred Marshall, in 1890, that Stern Stewart \& Co developed EVA. It was first used in the 1990s (Burksaitiene, 2009)

Economic Value Added (EVA) is based on the concept of economic profit or residual income, as it is also known. It is understood that a company creates wealth only when it supplies both operating and capital costs. Supplying them makes it possible for a company to conduct its performance (Young \& O'Byrne, 2002).

Assaf Neto, Araújo and Fregonesi (2006) add that EVA is a performance measure, which helps the company with its decision-making processes. EVA can be considered a variable for measuring economic return (Fatemi, Desai \& Katz, 2003). According to Gitman (2006), EVA is the measure the organizations use to indicate whether an investment is contributing positively to shareholder's wealth, or not.

According to Assaf Neto (2010), company's decisions related to financing area are focused on both value creation and shareholder's wealth increase. A company focused on value creation becomes more attractive to all stakeholders (Sobue \& Pepper, 2012). EVA allows not only aligning the interests of shareholders and executives but also those of people who occupy lower positions. EVA help managers focus on value creation, whether in everyday decisions or in investment decisions (Perez, 2000).

The ultimate goal of business is to maximize value, that is, to increase shareholders' economic value (Assaf Neto et al., 2006). Thus, EVA is used to evaluate companies. Through EVA one can check value creation and evaluate it, as well (Burksaitiene, 2009). Lovata and Costigan (2002) add that, when value of EVA is positive, this means that the company is creating value. Otherwise, this indicates that the company's investments do not cover their cost of capital.

According to Araujo and Assaf Neto (2003), EVA is the result of the company that exceeds the minimum compensation required by capital owners. EVA is considered a structure for management system dedicated to value analysis. This can contribute to decision-making process. Due to its simplicity and ability to help managers develop strategies toward value creation, EVA has been very attractive.

EVA is used to calculate wealth generated by a company in a given period of time and to check the profitability of the capital applied (Müller \& Telo, 2003). Santos and Watanabe (2005) argue that EVA is a quantitative measure determining the value created or 
destroyed by a company in a given period. Lovata and Costigan (2002) believe that companies using EVA have a higher percentage of institutional ownership.

Cunha and Frezatti (2004) praise EVA as a long-term financial indicator, which, together with other value indicators, seek to maximize the value of a company. Shareholders' view of wealth creation is the result of events such as: globalization, information technology advancement, greater liquidity in bond market, improvement in capital market regulation, change in younger generation's attitudes toward saving and investing, among others (Young \& O'Byrne, 2002).

A study on the relationship between information technology and competitive advantage was carried out by Vargas, Hernandez and Bruque (2003). They found that the factors explaining competitive advantage are both competitive intensity and company's ownership structure. Oliveira and Beuren (2003) found the accounting treatment that is given to intellectual capital, focusing on management in companies with market value higher than accounting value. They noted that the sampled companies did not use any accounting treatment structured to highlight intellectual capital. They had other tools to assist in management, as Evaluation System of Activity Plan (SAPA, in Portuguese), Management Information System (SIG, in Portuguese) and Economic Value Added, or EVA.

Kayo, Kimura and Basso (2005) have examined the participation of each intangible asset in generating economic results. They think $54.90 \%$ of value, generated by intangible assets, comes from relationship assets. Within this scenario, the brand corresponds to $87.50 \%$ of the value generated.

The relationship between information technology and financial performance, within companies, was examined by Shin (2006), who concludes that information technology improves company's financial performance.

Kayo et al. (2006) developed a theoretical study wishing to analyze strategies adopted by companies in relation to intangible assets, considering the product's life cycle and value creation process. Based on the analysis conducted, the authors found that different intangible assets may affect the company's value, depending on the product's life cycle.

Lin's (2007) study showed that information technology in banking companies can create value and competitive advantage. Lin indicates that both information technology capacity and human capital contribute to value creation. Radhakrishnan, $\mathrm{Zu}$ and Grover (2008) analyzed the relationship between information technology and business value and showed that information technology can improve financial measures and create competitive advantage.ui

A control instrument equipped with performance indicators was developed by Fischmann and Zilber (2009). They aimed at providing organization assessment, highlighting the proposals of both EVA and Balanced Scorecard. Fernandes (2012) adds that technology and knowledge are key factors in economic growth.

\section{METHODOLOGY}

Characterized as descriptive, this study was carried out by means of documentary research with quantitative approach to problem resolution. Its descriptive characteristics come from the fact that the study aims at investigating the relationship between financial performance, intangible assets and value creation of the companies surveyed. From Vergara's (2000, p. 47) point of view, "descriptive research exposes the characteristics of certain population or a certain phenomenon".

The procedure used was provided by documentary research, as described by Marconi and Lakatos (2010). The approach is quantitative due to the use of statistical tools in phases such as data collection, processing, and analysis, in accordance with Richardson's (1999) proposal. 
The survey sample includes Information Technology companies in Brazil and Chile, indexed on Thomson base. Nine companies were identified, five Brazilian and four Chilean, in the years 2008 to 2012. The values were dealt with in real currency, converted by the database.

The data used in the statistical analysis were extracted from Thomson base. They were considered the same data used in the studies mentioned in section 2.4. The variables are shown in Figure 1.

\section{Figure 1 - Variables Used in Study}

\begin{tabular}{|c|c|c|c|}
\hline Data & Variable & Proxy & Authors \\
\hline \multirow{2}{*}{ Dependent } & Intangible & Intangible Assets & $\begin{array}{l}\text { Surroca et al., (2010) e Tsai et al., } \\
\text { (2012). }\end{array}$ \\
\hline & EVA & $\begin{array}{l}\mathrm{EVA}=(\mathrm{ROI}-\mathrm{WACC}) * \\
\text { Investment }\end{array}$ & $\begin{array}{l}\text { Lovata e Costigan (2002) e Assaf } \\
\text { Neto (2010). }\end{array}$ \\
\hline \multirow{8}{*}{$\begin{array}{l}\text { Independent } \\
\text { Variables } \\
\text { measuring } \\
\text { financial } \\
\text { performance }\end{array}$} & ROA & Return on Assets & $\begin{array}{l}\text { Callan e Thomas (2009), Moneva } \\
\text { e Ortas (2010), Berman, Wicks, } \\
\text { Kotha e Jones (1999) e Choi e } \\
\text { Wang (2009). }\end{array}$ \\
\hline & ROE & Return on Equity & $\begin{array}{l}\text { Callan e Thomas (2009), Moneva } \\
\text { e Ortas (2010), } \\
\text { Preston e O'Bannon (1997) e } \\
\text { Agle, Mitchell, e Sonnenfeld } \\
\text { (1999). }\end{array}$ \\
\hline & Sales Growth & Sales Growth - 1 year & $\begin{array}{l}\text { Onusic, Casa Nova e Almeida } \\
\text { (2007) e Mahoney, Lagore e } \\
\text { Scazzero(2008) }\end{array}$ \\
\hline & ROS & $\begin{array}{l}\text { Return on Sales }=\text { Net } \\
\text { Earnings / Sales }\end{array}$ & $\begin{array}{l}\text { Waddock e Graves (1997) e } \\
\text { Callan e Thomas(2009). }\end{array}$ \\
\hline & ROCE & $\begin{array}{l}\text { Return on Invested } \\
\text { Capital }\end{array}$ & $\begin{array}{l}\text { Callan e Thomas (2009) e Girão, } \\
\text { Machado e Callado (2013). }\end{array}$ \\
\hline & LOB & $\begin{array}{l}\text { Operating Profit = } \\
\text { Gross Revenue - CMV }\end{array}$ & $\begin{array}{l}\text { Siqueira, Rosa e Oliveira (2003) e } \\
\text { Moneva e Ortas (2010). }\end{array}$ \\
\hline & Cash Flow & $\begin{array}{l}\text { Operating, financial, } \\
\text { investment }\end{array}$ & $\begin{array}{l}\text { Pace, Basso e Silva (2003) e } \\
\text { Moneva e Ortas (2010). }\end{array}$ \\
\hline & Share Earnings & Net Earnings / Share & $\begin{array}{l}\text { Pace et al., (2003) e Rostagno, } \\
\text { Soares e Soares (2006). }\end{array}$ \\
\hline
\end{tabular}

Source: Research Data.

For data analysis, descriptive statistics was first performed in order to describe research data. Later on, independent t-test was applied, which, according to Field (2009), is an effective technique when a categorizing variable is used as an explanatory variable. In the study, this technique was used to examine the effect of financial performance upon both value creation and intangible assets disclosure. It aimed at identifying whether Brazilian companies have greater or lesser financial performance regarding intangible assets and value creation than Chilean companies.

Pearson's correlation was applied to verify financial performance, value creation and intangible assets. It was also verified whether information technology companies with greater financial performance have more value creation and intangible assets disclosure, and whether they are Brazilian or Chilean. 


\section{DESCRIPTION AND ANALYSIS}

This section deals with description and analysis of research results. Initially, it shows descriptive analysis. The following step is the analysis of independent sample test. Soon after, Pearson's correlation is analyzed. Table 1 shows the descriptive analysis of data previously introduced in Figure 1, with descriptive statistics of variables.

Tabela 1 - Descriptive Statistics of Variables

\begin{tabular}{c|l|c|c|c|c}
\hline Companies & \multicolumn{1}{|c|}{ Variable } & Minimum & Maximum & Average & $\begin{array}{c}\text { Standard } \\
\text { Deviation }\end{array}$ \\
\hline \multirow{5}{*}{ Brazilian } & Intangible & 2,920 & 613,500 & 177,338 & 216,292 \\
\cline { 2 - 6 } & EVA & $-466,980$ & $2.086,537$ & 109,818 & 519,988 \\
\cline { 2 - 6 } & ROA & $-14,690$ & 16,820 & 5,199 & 7,811 \\
\cline { 2 - 6 } & ROE & $-23,920$ & 133,760 & 15,584 & 30,443 \\
\cline { 2 - 6 } & Sales Growth & $-17,690$ & 54,380 & 9,681 & 16,520 \\
\cline { 2 - 6 } & ROS & $-0,375$ & 0,163 & 0,020 & 0,115 \\
\cline { 2 - 6 } & ROCE & $-10,180$ & 24,970 & 8,141 & 8,430 \\
\cline { 2 - 6 } & Operating Profit & $-1.162,440$ & 419,110 & $-376,843$ & 575,589 \\
\cline { 2 - 6 } & Cash Flow & $-168,950$ & 871,680 & 127,135 & 183,687 \\
\cline { 2 - 6 } & Share Earnins & 0,000 & 0,050 & 0,013 & 0,017 \\
\hline \multirow{5}{*}{ Chilean } & Intangible & 0,000 & $1.013,880$ & 186,753 & 308,745 \\
\cline { 2 - 6 } & EVA & $-1.659,840$ & 263,220 & $-109,297$ & 494,317 \\
\cline { 2 - 6 } & ROA & $-2,630$ & 20,890 & 5,680 & 5,494 \\
\cline { 2 - 6 } & ROE & $-12,480$ & 23,410 & 6,211 & 8,331 \\
\cline { 2 - 6 } & Sales Growth & $-16,570$ & 59,370 & 9,083 & 19,063 \\
\cline { 2 - 6 } & ROS & $-0,121$ & 0,140 & 0,048 & 0,065 \\
\cline { 2 - 6 } & ROCE & $-2,980$ & 24,460 & 6,843 & 6,602 \\
\cline { 2 - 6 } & Operating Profit & $-1.963,900$ & 29,940 & $-597,491$ & 581,425 \\
\cline { 2 - 6 } & Cash Flow & $-509,900$ & 942,080 & 212,497 & 354,086 \\
\cline { 2 - 6 } & Share Earnings & 0,120 & 2,010 & 0,895 & 0,588 \\
\hline
\end{tabular}

Source: Research Data.

According to data presented in Table 1, which highlighted the descriptive statistics of the variables, it appears that, within information technology companies, the maximum and average values of the observed variables were balanced for the two countries.

At first glance, companies in Chile have a higher value of intangible assets for the five years analyzed. As for value creation variable (EVA), Brazilian companies showed better results when compared to companies from Chile, both as average maximum value. As for intangible assets, the results are consistent with both Barney's (1991) and Axtle-Ortiz's (2012) considerations. Barney believes that intangible assets contribute to competitive advantage; for Axtle-Ortiz (2012) intangible assets generate economic value to business. Regarding value creation (EVA), the result contributes to Burksaitiene's (2009) statement that, through EVA, one can check the value that is being generated by the company. Thus, it is assumed that there is relationship between financial performance, intangible assets disclosure and value creation.

However, to validate these findings, independent t-test was applied aiming at verifying whether the financial performance rates impact intangible assets disclosure and values creation, as Table 2, named Independent Sample Tests, shows: 
Table 2 - Independent Sample Tests

\begin{tabular}{|c|c|c|c|c|}
\hline \multicolumn{2}{|c|}{ Levene's Test for Variance Equality } & \multicolumn{2}{|c|}{$\begin{array}{c}\mathbf{F} \\
3,5164\end{array}$} & $\begin{array}{c}\text { Significant } \\
0,0685\end{array}$ \\
\hline \multicolumn{5}{|c|}{ T-Test for Average Equality } \\
\hline & & Test & $\begin{array}{c}\text { Differe } \\
\text { nt }\end{array}$ & $\begin{array}{c}\text { Significant (2 } \\
\text { ends) }\end{array}$ \\
\hline \multirow[b]{2}{*}{ Intangible } & Assumed Equal Variances & 0,113 & 38 & 0,910 \\
\hline & $\begin{array}{c}\text { Non-Assumed Equal } \\
\text { Variances } \\
\end{array}$ & 0,104 & 22,329 & 0,918 \\
\hline \multirow[b]{2}{*}{ EVA } & Assumed Equal Variances & $-1,314$ & 38 & 0,197 \\
\hline & $\begin{array}{c}\text { Non-Assumed Equal } \\
\text { Variances }\end{array}$ & $-1,331$ & 30,833 & 0,193 \\
\hline \multirow[b]{2}{*}{ ROA } & Assumed Equal Variances & 0,209 & 38 & 0,835 \\
\hline & $\begin{array}{l}\text { Non-Assumed Equal } \\
\text { Variances }\end{array}$ & 0,228 & 36,895 & 0,821 \\
\hline \multirow[b]{2}{*}{ ROE } & Assumed Equal Variances & $-1,161$ & 38 & 0,253 \\
\hline & $\begin{array}{l}\text { Non-Assumed Equal } \\
\text { Variances }\end{array}$ & $-1,451$ & 29,575 & 0,157 \\
\hline \multirow[b]{2}{*}{ Growth } & Assumed Equal Variances & $-0,105$ & 38 & 0,917 \\
\hline & $\begin{array}{c}\text { Non-Assumed Equal } \\
\text { Variances }\end{array}$ & $-0,101$ & 26,340 & 0,920 \\
\hline \multirow[b]{2}{*}{ ROS } & Assumed Equal Variances & 0,863 & 38 & 0,393 \\
\hline & $\begin{array}{c}\text { Non-Assumed Equal } \\
\text { Variances } \\
\end{array}$ & 0,986 & 37,933 & 0,331 \\
\hline \multirow[b]{2}{*}{ ROCE } & Assumed Equal Variances & $-0,509$ & 38 & 0,614 \\
\hline & $\begin{array}{l}\text { Non-Assumed Equal } \\
\text { Variances }\end{array}$ & $-0,541$ & 35,161 & 0,592 \\
\hline \multirow{2}{*}{$\begin{array}{l}\text { Operating } \\
\text { Profit }\end{array}$} & Assumed Equal Variances & $-1,169$ & 38 & 0,250 \\
\hline & $\begin{array}{l}\text { Non-Assumed Equal } \\
\text { Variances }\end{array}$ & $-1,166$ & 29,379 & 0,253 \\
\hline \multirow[b]{2}{*}{ Cash Flow } & Assumed Equal Variances & 1,006 & 38 & 0,321 \\
\hline & $\begin{array}{c}\text { Non-Assumed Equal } \\
\text { Variances }\end{array}$ & 0,866 & 18,603 & 0,397 \\
\hline \multirow{2}{*}{$\begin{array}{l}\text { Earning per } \\
\text { Share }\end{array}$} & Assumed Equal Variances & 7,552 & 38 & 0,000 \\
\hline & $\begin{array}{l}\text { Non-Assumed Equal } \\
\text { Variances }\end{array}$ & 5,801 & 36,895 & 0,000 \\
\hline
\end{tabular}

Source: Research Data.

Table 2 includes independent sample tests. It shows both Levene's Test and T-Test. It contains two lines, both bringing assumed and non-assumed equal variances. It also shows the values that result from T-Test. What Levene's test does is to test the hypothesis whether the variances in the two groups are the same, or not. Therefore, if the test is significant, one accepts variances are significantly different and, then, one should use data of equal variances not assumed. However, if Levene's test does not show significance, this means that variances are practically equal. One, then, should use the data of the assumed equal variances (Field, 2009).

As shown in Table 2, Levene's test was not significant at level of $5 \%$. That is, the variances are substantially equal. Thus, T-test was not significant either. This shows that 
there is no difference in financial performance for value creation and intangible assets in both Brazilian and Chilean information technology companies.

Table 3 shows Pearson's correlation. This refers to the relationship between the variables measuring Brazilian companies' financial performance, value creation and intangible assets. One observes that the correlation does not necessarily suggest a cause and effect relationship, but an association between the variables.

\section{Table 3 - Pearson's Correlation - Brazilian Companies}

\begin{tabular}{|c|c|c|c|c|c|c|c|c|c|c|c|}
\hline & & 焉 & 应 & 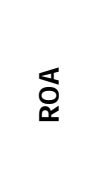 & 理 & 吾 & $\mathbb{E}_{\mathbb{1}}$ & 8 & 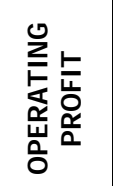 & $\begin{array}{l}3 \\
3 \\
3 \\
3 \\
3 \\
3\end{array}$ & 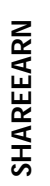 \\
\hline \multirow[t]{4}{*}{$\begin{array}{l}\text { INTANGIBLE } \\
\text { EVA }\end{array}$} & Correlation & 1 & & & - & - & & & & & - \\
\hline & Significant & & - & - & - & - & 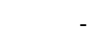 & - & - & - & - \\
\hline & Correlation & $0,627^{* *}$ & 1 & - & - & - & . & - & 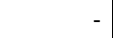 & - & - \\
\hline & Significant. & 0,001 & & & - & - & - & - & & - & - \\
\hline \multirow[t]{2}{*}{ ROA } & Correlation & $0,601^{* *}$ & $0,396^{*}$ & 1 & - & - & - & - & - & - & - \\
\hline & Significant & 0,001 & 0,050 & & 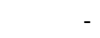 & 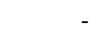 & & - & & - & - \\
\hline \multirow[t]{2}{*}{ ROE } & Correlation & $-0,006$ & 0,148 & $-0,252$ & 1 & - & - & - & - & - & - \\
\hline & Significant & 0,976 & 0,481 & 0,223 & & - & & - & & 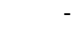 & - \\
\hline \multirow[t]{2}{*}{ GROWTH } & Correlation & $0,564^{* *}$ & 0,393 & $0,542^{* *}$ & 0,179 & 1 & 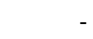 & - & - & 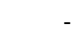 & - \\
\hline & Significant. & 0,003 & 0,052 & 0,005 & 0,392 & & - & - & - & - & - \\
\hline \multirow[t]{2}{*}{ ROS } & Correlation & $0,543^{* *}$ & 0,307 & $0,921^{* *}$ & $-0,440^{*}$ & $0,476^{*}$ & 1 & - & - & - & - \\
\hline & Significant & 0,005 & 0,136 & 0,000 & 0,028 & 0,016 & & - & & - & - \\
\hline \multirow[t]{2}{*}{ ROCE } & Correlation & $0,480^{*}$ & 0,380 & $0,899^{* *}$ & 0,130 & $0,580^{* *}$ & $0,707^{* *}$ & 1 & & - & - \\
\hline & Significant & 0,015 & 0,061 & 0,000 & 0,537 & 0,002 & 0,000 & - & - & - & - \\
\hline \multirow{2}{*}{ OP.PROFIT } & Correlation & $0,619^{* *}$ & $0,432^{*}$ & 0,124 & 0,210 & 0,188 & 0,076 & 0,077 & 1 & - & - \\
\hline & Significant & 0,001 & 0,031 & 0,555 & 0,313 & 0,368 & 0,718 & 0,714 & & - & - \\
\hline \multirow[t]{2}{*}{ CASHFLOW } & Correlation & $0,626^{* *}$ & 0,089 & $0,408^{*}$ & $-0,060$ & $0,689^{* * *}$ & 0,338 & 0,344 & 0,202 & 1 & - \\
\hline & Significant & 0,001 & 0,673 & 0,043 & 0,776 & 0,000 & 0,098 & 0,093 & 0,333 & & - \\
\hline \multirow[t]{2}{*}{ SHAREEARN } & Correlationt &,$- 404^{*}$ & $-0,361$ & 0,010 & $-0,229$ & $-0,128$ & 0,073 & $-0,019$ & $-0,715^{* *}$ & -257 & 1 \\
\hline & Significant & 0,045 & 0,076 & 0,961 & 0,271 & 0,541 & 0,730 & 0,929 & 0,000 & ,216 & \\
\hline
\end{tabular}

** Correlation is significant at level of 0,01 (2 ends).* Correlation is significant at level of 0,05 (2 ends).Source: Research Data.

According to the findings in Table 3, named Pearson's correlation, a significant relationship was found between the variables supporting the idea that a company's better financial performance interferes with both intangible assets disclosure and value creation. Thus, variables showing significance of $1 \%$ ( 2 ends) for the correlation were EVA, ROA, sales growth, ROS, operating profit and cash flow. The variables ROE, ROCE and share earnings were not statistically significant (2 ends) to intangible variable in Pearson's correlation. The same is true to all variables analyzed, which has no effect on value creation.

It is observed also in Table 3 that variables EVA (63\%), ROA (60\%), sales growth (56\%), ROS (54\%), operating profit (62\%) and cash flow (63\%) have a positive correlation with the intangible, with significance at level of 0.01 . That is, the higher EVA, ROA, sales growth, ROS, operating profit and cash flow are the greater the intangible assets disclosure is.

The findings can be considered similar to the results obtained by Surroca et al., (2010), indicating there is no direct relationship between financial performance and intangible assets disclosure. However, this seems to depend on the mediating effect of value creation.

Unlike the results obtained by Silva, Rodrigues and Dueñas (2012) indicating that the larger the company is in terms of financial performance, the more disclosure of 
intangible assets it will have. Thus, the mediating effect of Surroca et al. (2010) will not be needed.

Table 4 shows Pearson's correlation in Chilean Information Technology companies.

Table 4 - Pearson's Correlation - Chilean Companies

\begin{tabular}{|c|c|c|c|c|c|c|c|c|c|c|c|}
\hline & & 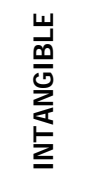 & 厌 & 8 & 䅂 & 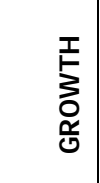 & 8 & 8 & 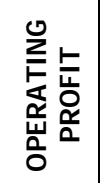 & 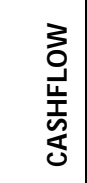 & 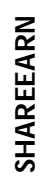 \\
\hline INTANGIVEL & $\begin{array}{l}\text { Significant } \\
\text { Correlation }\end{array}$ & 1 & - & - & - & - & - & - & - & -1 & \\
\hline EVA & Significant & 0,297 & 1 & - & - & - & - & - & - & - & 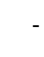 \\
\hline \multirow[t]{2}{*}{ ROA } & $\begin{array}{l}\text { Correlation } \\
\text { Significant. }\end{array}$ & $\begin{array}{l}0,282 \\
0,309\end{array}$ & 0,488 & i & - & $\begin{array}{l}- \\
-\end{array}$ & $\begin{array}{l}- \\
-\end{array}$ & $\begin{array}{l}- \\
-\end{array}$ & $\begin{array}{l}- \\
-\end{array}$ & $\begin{array}{l}- \\
-\end{array}$ & - \\
\hline & Correlation & 0,263 & 0,065 & - & - & - & - & - & - & - & - \\
\hline \multirow[t]{2}{*}{ ROE } & Significant. & 0,404 & $0,736^{* *}$ & $0,946^{* *}$ & 1 & - & - & - & - & - & - \\
\hline & Correlation & 0,136 & 0,002 & 0,000 & & $=$ & - & - & - & 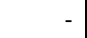 & - \\
\hline \multirow[t]{2}{*}{ GROWTH } & Significant & 0,434 & 0,185 & 0,166 & 0,203 & 1 & - & - & - & - & - \\
\hline & Correlation & 0,106 & 0,508 & 0,554 & 0,468 & & - & - & - & -1 & - \\
\hline \multirow[t]{2}{*}{ ROS } & Significant & 0,205 & $0,830^{* *}$ & $0,794^{* *}$ & $0,908^{* *}$ & 0,016 & 1 & - & - & 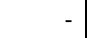 & - \\
\hline & Correlation & 0,464 & 0,000 & 0,000 & 0,000 & 0,954 & & - & . & - & - \\
\hline \multirow[t]{2}{*}{ ROCE } & Significant & 0,381 & 0,490 & $0,996^{* *}$ & $0,949^{* *}$ & 0,205 & $0,776^{* *}$ & 1 & - & - & - \\
\hline & Correlation & 0,161 & 0,064 & 0,000 & 0,000 & 0,463 & 0,001 & & - & - & \\
\hline \multirow[t]{2}{*}{ OP.PROFIT } & Significant & $-0,574^{*}$ & $-0,350$ & $-0,849^{* *}$ & $-0,791^{* *}$ & $-0,337$ & $-0,545^{*}$ & $-0,874^{* *}$ & 1 & - & - \\
\hline & Correlation & 0,025 & 0,200 & 0,000 & 0,000 & 0,220 & 0,036 & 0,000 & & - & \\
\hline \multirow[t]{2}{*}{ CASHFLOW } & Significant & $0,554^{*}$ & 0,117 & $-0,240$ & $-0,110$ & $-0,037$ & $-0,101$ & $-0,202$ & 0,068 & 1 & \\
\hline & Correlation & 0,032 & 0,677 & 0,388 & 0,696 & 0,896 & 0,721 & 0,470 & 0,811 & & - \\
\hline \multirow[t]{2}{*}{ SHAREEARN } & Significant & $0,735^{* *}$ & 0,038 & 0,050 & 0,112 & 0,367 & $-0,071$ & 0,113 & $-0,117$ & 0,483 & 1 \\
\hline & Correlation & 0,002 & 0,893 & 0,861 & 0,690 & 0,179 & 0,803 & 0,687 & 0,678 & 0,068 & \\
\hline
\end{tabular}

** Correlation is significant at level of 0,01 (2 ends). * Correlation is significant at level of 0,05 (2 ends).

Source: Research Data.

The findings in Table 4, entitled Pearson's Correlation, depict a significant relationship between the variables supporting the idea that a better financial performance of the company interferes with intangible assets disclosure and value creation. Thus, the variables showing significance of $1 \%$ ( 2 ends) for the correlation were ROE, ROS and share earnings in both assets disclosure and value creation.

The variables ROA, growth, ROCE, operating profit and cash flow were not statistically significant ( 2 ends) to intangible variables and value, regarding Pearson's correlation.

It is observable also, in Table 4, that the variables ROE (74\%), ROS (83\%) and share earnings (74\%) show positive correlation with intangible and value creation, with significance at level 0,01 . That is, the higher the variables ROE, ROS and share earnings, the greater the intangible assets disclosure and value creation within Chilean information technology companies are.

The findings can be considered similar to the results obtained by Silva et al. (2012), in which the larger the company is, the more intangible assets disclosure it will have. As for value creation, Cunha and Frezatti (2004) state that, in conjunction with other financial indicators, intangible assets seek to maximize the company's value.

These results show differences in relation to the assumptions defended by Surroca et al. (2010). This is due to the fact that there is no mediating effect between intangible assets disclosure and financial performance, as in the case of Brazilian Information Technology companies. 
Given the findings, it is seen that, in order to disclose intangible assets, Brazilian information technology companies are in need of both value creation and financial performance. Within Chilean companies, only financial performance affects intangible assets disclosure and value creation.

\section{CONCLUDING REMARKS}

This study aimed at, specifically, analyzing the relationship between financial performance with intangible assets disclosure and value creation within Brazilian and Chilean information technology companies. To achieve the proposed goal a descriptive research with quantitative approach by means of documental analysis was carried out. The research had as sample Brazilian and Chilean Information Technology companies, indexed on Thomson ${ }^{\circledR}$ base. These were five Brazilian and four Chilean companies, totaling nine, for the period 2008 to 2012. One worked with the values in real currency, converted by the database.

The analysis of the results used statistical tests, as follows: (i) descriptive statistics for research data description; (ii) independent t-test to see which country showed the best relationship between financial performance, value creation and intangible assets; and (iii) Pearson's correlation.

The first results obtained with the use of descriptive statistics provided evidence that there is an average result within the companies for both countries. The findings presented by independent t-test confirmed these results. However, the findings showed by Pearson's correlation depicted financial performance keeping association with intangible assets disclosure.

Finally, Pearson's correlation within Chilean companies mostly depicted the relationship. Thus, the financial performance of Chilean information technology companies interfered with both value creation and intangible assets disclosure.

From the results obtained in this study one may conclude that Chilean companies showed greater impact on both intangible assets disclosure and value creation, through financial performance within the companies surveyed. However, in order to deal with intangible assets disclosure, Brazilian information technology companies need value creation and financial performance.

For further studies additional analysis of a longer period is recommended, with extended sample of companies and other variables, which will project a wider view of the results.

\section{REFERENCES}

Agle, B. R., Mitchell, R. K. \&Sonnenfeld, J. A. (1999). Who matters to CEOs? An investigation of stakeholders attributes and salience, corporate performance and CEO values. Academy of Management Journal, 42(5), 507-525.

Araújo, A. M. P. de \&Assaf Neto, A. (2003).A contabilidade tradicional e a contabilidade baseada em valor. Revista Contabilidade \& Finanças, 14 (33), 16-32.

Aravena, C., Cavada, C. \&Mulder, N. (2012). Contribución al crecimiento económico de las tecnologías de la información y las comunicaciones y de la productividad en la Argentina, el Brasil, Chile y México. CEPAL - Serie Estudios estadísticos y prospectivos, 76, 1-33.

Assaf Neto, A. (2003). Estrutura e análise de balanços: um enfoque econômico-financeiro. 8. ed. São Paulo: Atlas.

Assaf Neto, A. (2010).Finanças Corporativas e Valor. 5 ed. São Paulo: Atlas. Assaf Neto, A.(2012).Finanças corporativas e valor. 6. ed. São Paulo: Atlas. 
Assaf Neto, A., Araújo, A. M. P. de \&Fregonesi, M. S. F. do A. (2006). Gestão baseada em valor aplicada ao terceiro setor. Revista Contabilidade \& Finanças-USP, 105-118.

Axtle-Ortiz, M. A. (2012). Perceiving the value of intangible assets in context.Journal of Business Research, 66, 417-424.

Barney, J. (1991). Firm resources and sustained competitive advantage. Journal of Management, 17, 99-120.

Bastos, D. D. \& Nakamura, W. T. (2009). Determinantes da estrutura de capital das companhias abertas no Brasil, México e Chile no período 2001-2006. Revista Contabilidade \& Finanças-USP, 20 (50), 75-94.

Bastos, D. D., Nakamura, W. T. \& Basso, L. F. C. (2009). Determinants of capital structure of publicly-traded companies in latin america: an empirical study considering macroeconomic and institutional factors. RAM. Revista de Administração Mackenzie, 10 (6), 47-77.

Berman, S. L., Wicks, A. C., Kotha, S. \&JONES, T. M. (1999). Does stakeholder orientation matter? the relationship between stakeholder management models and firm financial performance. Academy of Management Journal, 42 (5) , 488-506.

Boaventura, J. M. G., Silva, R. S. da \& Bandeira-De-Mello, R. (2012). Performance Financeira Corporativa e Performance Social Corporativa: desenvolvimento metodológico e contribuição teórica dos estudos empíricos. Revista Contabilidade \& Finanças - USP, 23(60), 232-245.

Borba, P. da R. F. (2005). Relação entre desempenho social corporativo e desempenho financeiro de empresas no Brasil. Dissertação de Mestrado em Administração, Universidade de São Paulo, São Paulo, SP, Brasil.

Brito, L. A. L. \& Ferreira, F. C. M. (2008). Os efeitos da produtividade e escala no desempenho financeiro das empresas de Tecnologia de Informação. Revista de Administração Mackenzie, 9 (3), 38-57.

Burksaitiene, D. (2009). Measurement of value creation: Economic value added and net present value. Economics \& Management, 14, 709-714.

Callan, S. J. \& Thomas, J. M. (2009). Corporate financial performance and corporate social performance: an update and reinvestigation. Corporate Social Responsibility and Environmental Management, 16 (2), 61-78.

Choi, J. \& Wang, H. (2009). Stakeholder relations and the persistence of corporate financial performance. Strategic Management Journal, 30 (4), 895-907.

Ciprian, G. G., Valentin, R. Madalina, G.A. \& Lucia, V.M. (2012). From Visible to Hidden Intangible Assets. Procedia-Social and Behavioral Sciences, 62, 682-688.

Cochran, P. L., Wood, R. A. (1984). Corporate social responsibility and financial performance. Academy of Management Journal, 27 (1), 42-56.

CPC- Pronunciamento Técnico CPC 04 (R1) (2010). Ativo Intangível. Brasília, DF. Recuperado em 30 outubro, 2013, de http:/ / cpc.org.br.

Costa, F. \& Garcias, P.M. (2009). Concentração de mercado e desempenho das indústrias brasileiras de papel e celulose - recorrendo à modelagem de Fleuriet para analisar o paradigma ECD. RCO - Revista de Contabilidade e Organizações, 3 (6) , 143-163.

Cunha, D. R. \&Frezatti, F. (2004). Gestão baseada em valor: uma pesquisa no setor hoteleiro do Rio Grande do Norte. Revista de Administração,10 (4).

Fatemi, A., Desai, A. S. \&Katz, J. P. (2003). Wealth creation and managerial pay: MVA and EVA as determinants of executive compensation. Global Finance Journal, 14 (2), 159-179. 
Fischmann, A. A. \& Zilber, M. A. (2009). Utilização de indicadores de desempenho para a tomada de decisões estratégicas: um sistema de controle. Revista de Administração Mackenzie, 1 (1), 9-25.

Fernandes, A. S. C. (2012). Assessing the technology contribution to value added.Technological Forecasting and Social Change, 79 (2), 281-297.

Field, A. (2009). Descobrindo a estatística usando o SPSS. 2. ed. Porto Alegre: Artmed. Gasparetto, V. (2004). O papel da contabilidade no provimento de informações para a avaliação do desempenho empresarial. Revista Contemporânea de Contabilidade, 1(2), 109122.

Girão, L. F. de A. P., Machado, M. A. V. \& Callado, A. L. C. (2013). Análise dos Fatores que Impactam o MVA das Companhias Abertas Brasileiras: Será o EVA® mais Value Relevant que os Indicadores de Desempenho Tradicionais? Sociedade, Contabilidade e Gestão, 8 (2) , 89105.

Gitman, L. J. (2006).Princípios de administração financeira. 2 ed. Porto Alegre: Bookman. Gitman, L. J.(2010).Princípios de Administração Financeira. 12 ed. São Paulo: Pearson. Groppelli, A.A. \& Nikbakht, E. (2002) Administração Financeira. 2 ed. São Paulo: Saraiva. Horngren, C. T. (1985). Introdução à Contabilidade Gerencial. 5 ed. Rio de Janeiro: PrenticeHall do Brasil.

Hendriksen, E. S. \& Van Breda, M. F. (1999).Teoria da contabilidade. Tradução de Antonio Zoratto Sanvicente. 1. ed. São Paulo: Atlas.

Iudícibus, S. de, Martins, E., Gelbck, E. R. \& Santos, A. dos. (2010).Manual de contabilidade societária: aplicável a todas as sociedades de acordo com as normas internacionais e do CPC. São Paulo: Atlas.

Jiambalvo, J .(2002). Contabilidade Gerencial. Rio de Janeiro: LTC.

Kayo, E. K., Kimura, H. \& Basso, L. F. C. (2005). Avaliação de ativos intangíveis e analytic hierarchy process: um ensaio sobre a hierarquização dos direcionadores não-financeiros de valor. GESTÃO. Org-Revista Eletrônica de Gestão Organizacional, 3 (3), 230-241.

Kayo, E. K., Kimura, H., Martin, D. M.L. \& Nakamura, W. T. (2006). Ativos intangíveis, ciclo de vida e criação de valor. Revista de administração contemporânea, 10 (3), 73-90.

Lev, B. (2001).Intangibles: management and reporting. Washington: Brookings.

Lima, A. C. \&Carmona, C.U. (2011).Determinantes da formação do capital intelectual nas empresas produtoras de tecnologia da informação e comunicação. RAM. Revista de Administração Mackenzie, 12 (1), 112-138.

Lin, B. (2007). Information technology capability and value creation: Evidence from the US banking industry.Technology in Society, 29 (1), 93-106.

Lovata, L. M.\& Costigan, M. L. (2002). Empirical analysis of adopters of economic value added.Management Accounting Research, 13 (2), 215-228.

Mahoney, L. S., Lagore, W. \& Scazzero, J. A. (2008). Corporate social performance, corporate financial performance for firms that restate earnings. Issues in Social and Environmental Accounting, 2 (1), 104-130.

Mahoney, L. \& Roberts, R. (2004). Corporate Social and Environmental Performance and Their Relation to Financial Performance and Institutional Ownership: Empirical Evidence on Canadian Firms. Research on Professional Responsibility and Ethics in Accounting.

Marcon, R., Grzebieluckas, C., Bandeira-De-Mello, R. \& Muller, R. de A. (2007).O comportamento da estrutura de capital ea performance de firmas brasileiras, argentinas e chilenas. Revista de Gestão USP, 14 (2), 33-48. 
Marconi, M. de A. \& Lakatos, E. M. (2010).Fundamentos de metodologia científica. 7. ed. São Paulo: Atlas.

Mcguire, J. B., Sundgren, A. \&Schneeweis, T. (1988). Corporate social responsibility and firm financial performance. Academy of Management Journal, 31 (4), 854-872.

Moneva, J. M. \& Ortas, E. (2010). Corporate environmental and financial performance: a multivariate approach. Industrial Management \& Data Systems, 110 (2), 193-210.

Müller, A. N. \& Teló, A. R. (2003). Modelos de avaliação de empresas. Revista FAE, Curitiba, 6 (2), 97-112.

Niculita, A. L.; Popa, A. F. \&Caloian, F. (2012). The Intangible Assets-A New Dimension in The Company's Success.Procedia Economics and Finance, 3, 304-308.

Oliveira, J. M. de \& Beuren, I. M. (2003). O tratamento contábil do capital intelectual em empresas com valor de mercado superior ao valor contábil. Revista Contabilidade \& Finanças, 14 (32), 81-98.

Onusic, L. M., Casa Nova, S. P. de C. \&Almeida, F. C. de. (2007). Modelos de previsão de insolvência utilizando a análise por envoltória de dados: aplicação a empresas brasileiras. Revista de Administração Contemporânea, 11(SPE2), 77-97.

Orlitzky, M., Schmidt, F. L. \& Rynes, S. L. (2003).Corporate social and financial performance: a meta-analysis. Organization Studies, 24(3), 403-441.

Pace, E. S. U., Basso, L. F. C. \& Silva, M. A. da. (2003). Indicadores de desempenho como direcionadores de valor. Revista de Administraçao Contemporânea, 7 (1), 37-65.

Perez, A. J. da C. (2000). EVA: Economic Value Added: resumo e aplicação da metodologia. Dissertação apresentada ao Curso de Pós Graduação da FGV/ EAESP.

Perez, M. M. \& Famá, R. (2006). Ativos intangíveis e o desempenho empresarial. Revista Contabilidade \& Finanças, 17(40), 7-24.

Preston, L. E. \& O'Bannon, D. P. (1997). The corporate social-financial performance relationship. Business and Society, 36 (4), 419-429.

Radhakrishnan, A., Zu, X. \& Grover, V. (2008). A process-oriented perspective on differential business value creation by information technology: An empirical investigation. Omega, 36 (6), 1105-1125.

Richardson, R. J. (1999). Pesquisa social: métodos e técnicas. 3. ed. São Paulo: Atlas. Rogers, P., Mendes-Da-Silva, W. \& PAULA, G. de. (2005). Estratégias corporativas de diversificação e valor das empresas na América Latina: estudo de caso do Brasil. Asamblea Consejo Latinoamericano de Escuelas de Administracion (Cladea), 40.

Rostagno, L.; Soares, R. O\& Soares, K. T. C. (2006). Estratégias de valor e de crescimento em ações na Bovespa: Uma análise de sete indicadores relacionados ao risco. Revista Contabilidade \& Finanças, 17 (42), 7-21.

Santos, J. O. dos \& Watanabe, R. (2005). Uma análise da correlação entre o EVA® e o MVA® no contexto das empresas brasileiras de capital aberto. Caderno de Pesquisas em Administração, 12 (1), 19-32.

Shin, N. (2006). The impact of information technology on the financial performance of diversified firms. Decision Support Systems, 41 (4), 698-707.

Silva, M. D. L. R. D., Rodrigues, A. M. G. \&Dueñas, M. D. P. (2012). Disclosure of intangible assets: an empirical study of financial corporations in the Iberian Peninsula. Facoltà di Economia dell'Università di Salerno, 2012. Disponível em:

〈https:/ / estudogeral.sib.uc.pt/ jspui/ handle/ 10316/ 21287>. Acesso em: 27 fev. 2013. Siqueira, M., Rosa, E. B. \&Oliveira, A. F. de. (2003). Medindo o desempenho das pequenas indústrias de malhas: um estudo de caso. Revista Economia \& Gestão, 3 (6) , 109-127. 
Sobue, M. A. \& Pimenta, T.,Jr. (2012). A Relação entre a Geração de Valor Econômico e o Valor de Mercado das Empresas Sucroalcooleiras Brasileiras. Revista Contemporânea de Contabilidade, 9 (17), 103-120.

Solomon, E. \&Pringle, J. J. (1981). Introdução a administração financeira.São Paulo: Atlas. Surroca, J., Tribó, J. A. \& Waddock, S. (2010). Corporate responsibility and financial performance: the role of intangible resources. Strategic Management Journal, 31 (3), 463490.

Teixeira, J. P., Petri, S. M.\& Marques, T. de O. (2012). O valor da marca como um ativo intangível: um estudo de caso da WEG SA. Revista de Contabilidade do Mestrado em Ciências Contábeis da UERJ, 17 (2), 45-67.

Trentin, G. N. S. (2009). Os elementos da cultura que fazem parte do ambiente inovador e os indicadores de desempenho econômico-financeiros. Dissertação de Mestrado apresentada ao Programa de Pós-Graduação em Administração do Centro de Ciências Sociais Aplicadas, Universidade Regional De Blumenau, Santa Catarina, Brasil.

Tsai, C., Lu, Y. \& Yen, D. C. (2012). Determinants of intangible assets value: The data mining approach. Knowledge-Based Systems, 31, 67-77.

Vargas, A, Hernández, M. J. \& Bruque, S. (2003). Determinants of information technology competitive value. Evidence from a western European industry. The journal of high technology management research, 14 (2), 245-268.

Vergara, S. C. (2000). Projetos e relatórios de pesquisa em administração. 3. ed. São Paulo: Atlas.

Vicenti, T., Starosky, L., Filho\& Toledo, J. R. de, Filho. (2012). Evidenciação das inovações realizadas pelas empresas de tecnologia da informação. Revista de Contabilidade do Mestrado em Ciências Contábeis da UERJ, 17 (2), 104-121.

Waddock, S.A \& Graves, SB. (1997). The corporate social performance-financial performance link. Strategic Management Journal, 18 (4), 303-319.

Young, S. D. \&O'Byrn, S. F. (2002). EVA e gestão baseada em valor. Bookman.

Note: A version in Portugues may be available at the Journal Website.

Revista Galega de Economia / Economic Review of Galicia: http:/ / www.usc.es/ econo/ RGE/ benvidag.htm http:// ideas.repec.org/ s/ sdo/ regaec.html 